\title{
The effect of bypass protein supplementation on the reproductive performance of Merino sheep grazing mixed karoo veld
}

\author{
J.H. Hoon, M.J. Herselman, M. van Heerden and A.P. Pretorius \\ Grootfontein A.D.I., P/Bag X529, Middelburg, 5900, South Africa \\ Email: dier12@karoo1.agric.za
}

\section{Introduction}

Ewe productivity is one of the most important factors that determine the profitability of small stock farming. The most important components of ewe productivity are the total weight of lamb produced, body weight at culling and, in the case of wool producing sheep, the amount and quality (mainly fibre diameter) of the wool. From 65 to $88 \%$ of the total income from wool sheep is derived from mutton, while it is even higher in the case of mutton sheep. This emphasises the importance of increasing the kilograms of meat produced per hectare in order to increase ewe productivity and thus profitability. Probably the easiest way to do it is by increasing the weaning percentage of the ewes and the growth rate of the lambs. Although weaning percentage can be enhanced by increasing the conception rate of ewes and number of multiple births, the best option is probably to decrease the lamb mortality rate. Most lamb mortalities $( \pm 80 \%)$ occur in the period just before birth until seven days after birth and research has shown that nearly $80 \%$ of these mortalities are related to the nutrition of the ewe during the last weeks before lambing and the first weeks after lambing (Seymour, 1998). The amount of colostrum available at lambing and the milk production of the ewe after lambing are important factors influencing lamb survival and growth rate of lambs. The supply of sufficient protein during late pregnancy and lactation influences the quantity as well as quality of milk produced. Research results suggested that the supply of a high level of bypass protein (rumen undegradable protein) is essential to increase the colostrum and milk production of ewes (Hinch et al., 1996). The high cost associated with supplementation of reproducing ewes, especially with bypass protein sources, necessitate further investigations into this matter. This study investigated the effect of bypass protein supplementation on the reproductive performance of Merino sheep on Mixed Karoo veld

\section{Material and Methods}

The study was carried out over a period of two years (1998-1999) under natural veld conditions (Mixed Karoo veld) at Grootfontein A.D.I. near Middelburg in the Eastern Cape. In 1998, 351 Merino ewes were randomly divided into three equal groups and grazed camps comparable in size and vegetation type. The three groups were rotated every two weeks between camps to eliminate any possible camp effects. Treatment 1 received no supplementation (Control), treatment 2 received a urea-based supplement (Urea) and treatment 3 a bypass proteinbased supplement (Bypass). All the diets contained the same amount of total energy and protein ( $\mathrm{N}$ x 6.25). Supplementary feeding was supplied from four weeks before lambing until eight weeks after lambing. Intakes of supplements were limited to 300 and $400 \mathrm{~g} / \mathrm{sheep} /$ day for pregnant and lactating ewes respectively. The experiment was repeated in 1999. All the ewes were allocated to the same treatment groups as the previous year and replacement ewes were randomly divided among the groups. The following data were recorded for both years: birth weight, 42 day weight and weaning weight of lambs, number of lambs born and weaned and lamb mortalities. Milk composition of five ewes from each group was determined every two weeks for the full lactation period in 1998, while milk production of each ewe was recorded three weeks after lambing in 1999. Statistical analyses on reproduction data were performed by using the FREQ procedures of SAS and tested for significance by Chi-square. Statistical analyses of body weight of lambs were performed using the GLM procedures of SAS. The model included sex, year, treatment, age of dam, status (birth, 42 day and weaning), age of lamb and a year $\mathrm{x}$ treatment interaction. The effects were tested against the residual error, while least-squares means were separated using the PDIFF option of SAS (Littell et al., 1991). The milk production data recorded in 1999 were also analysed with the GLM procedures, but the model only included treatment, age of ewe and number of suckling lambs. Milk composition data (only collected in 1998) were analysed as a split-plot, repeated measures design. The model included treatment and week of lactation. The treatment effect was tested using animal within treatment as error term, while least-squares means were separated as mentioned before. 


\section{Results and Discussion}

The reproduction data of the ewes in 1999 that received the same treatment as in 1998, the growth data of the lambs of both years and the milk composition (1998) and milk production (1999) of the ewes are presented in Table 1.

Table 1 Reproduction and milk production data of ewes and growth data of lambs

\begin{tabular}{|c|c|c|c|}
\hline & Control & Urea & Bypass \\
\hline \multicolumn{4}{|l|}{ Reproduction data of ewes (1999) } \\
\hline Ewes lambed/ewes mated $(\%)$ & 72.2 & 78.9 & 78.0 \\
\hline Lambs born/ewes mated (\%) & 83.3 & 91.5 & 95.1 \\
\hline Lambs weaned/ewes mated (\%) & 69.4 & 84.5 & 79.3 \\
\hline $\mathrm{Kg}$ lamb weaned/ewe & $17.46 \pm 1.93$ & $21.90 \pm 1.98$ & $20.34 \pm 1.88$ \\
\hline Gross Margin (R/ha) & 58.39 & 63.55 & 59.27 \\
\hline \multicolumn{4}{|l|}{ Data of lambs (1998 and 1999) } \\
\hline Lambs - Birth weight $(\mathrm{kg})$ & $4.23 \pm 0.12^{\mathrm{a}}$ & $4.40 \pm 0.12^{\mathrm{b}}$ & $4.27 \pm 0.12$ \\
\hline Lambs - 42-day weight (kg) & $13.23 \pm 0.62^{\mathrm{a}}$ & $15.02 \pm 0.63^{\mathrm{b}}$ & $15.01 \pm 0.62^{b}$ \\
\hline Lambs - Weaning weight (kg) & $23.49 \pm 0.94^{\mathrm{a}}$ & $24.33 \pm 0.94^{\mathrm{b}}$ & $23.79 \pm 0.93$ \\
\hline Lamb mortality rate $(\%)$ & 17.5 & 13.0 & 12.2 \\
\hline \multicolumn{4}{|l|}{ Milk composition (1998) } \\
\hline Fat $(\%)$ & $7.04 \pm 0.33$ & $6.73 \pm 0.33^{\mathrm{a}}$ & $7.95 \pm 0.34^{\mathrm{b}}$ \\
\hline Protein $(\%)$ & $4.33 \pm 0.10$ & $4.40 \pm 0.10$ & $4.54 \pm 0.11$ \\
\hline Lactose $(\%)$ & $4.86 \pm 0.10^{\mathrm{a}}$ & $4.53 \pm 0.10^{b}$ & $4.86 \pm 0.10^{\mathrm{a}}$ \\
\hline \multicolumn{4}{|l|}{ Milk production (1999) } \\
\hline Daily milk production (ml/ewe) & $1034 \pm 45^{\mathrm{a}}$ & $1404 \pm 44^{\mathrm{b}}$ & $1352 \pm 43^{\mathrm{b}}$ \\
\hline
\end{tabular}

${ }^{\mathrm{ab}}$ Values with different superscripts differ significantly $(\mathrm{P}<0.05)$

The reproduction data of the ewes, including the total weight of lamb weaned/ewe, did not differ $(\mathrm{P}>0.05)$ among the different treatments, although all the traits tended to be lower for the Control group. These results indicate that the supplementation of the ewes in 1998 did not have a significant effect on the reproduction data of the same ewes in 1999. The data of the lambs (1998 and 1999) indicate that the birth weight and weaning weight of the lambs of the Urea group was higher $(\mathrm{P}<0.05)$ than that of the Control group. The 42-day weight of the lambs of the Control group was lower $(\mathrm{P}<0.05)$ than that of the Urea and Bypass groups. Factors like sex, age of dam, status of lamb and treatment $x$ year interaction had a significant effect $(\mathrm{P}<0.01)$ on the lamb data. The milk composition data (1998) indicated that the fat content of the Bypass group was higher $(\mathrm{P}<0.05)$ than that of the Urea group, while the lactose content of both the Control and Bypass groups were higher $(\mathrm{P}<0.05)$ than the Urea group. The daily milk production of the ewes (1999) of the Control group was lower $(\mathrm{P}<0.05)$ than that of the Urea and Bypass groups.

\section{Conclusions}

The results of this study suggest that supplementation of ewes during late pregnancy and lactation on Mixed Karoo veld in general had a positive effect on their reproductive performance. Economic calculations also favour the supplementation groups, although much more data are needed to reach a final conclusion. From this study, it is, however, evident that supplementation of reproducing Merino ewes on Mixed Karoo veld with bypass protein sources had no advantage over supplementation with urea sources.

\section{References}

Hinch, G.N., Lynch, J.J., Nolan, J.V., Leng, R.A., Bindon, B.M. \& Piper, L.R., 1996. Supplementation of high fecundity Border Leicester x Merino ewes with a high protein feed: its effect on lamb survival. Austr. J. of Exp. Agric. 36, 129-136.

Littell, R.C., Freud, R.J. \& Spector, P.C., 1991. SAS System for Linear Models. Third Edition. SAS Institute Inc., Cary. NC.

Seymour, M., 1998. Monitor ewe nutrition for healthy lambs. Farming Ahead, May 1998, 77, 77-78. 